\title{
Groundwater Contamination Issues in Chiniot Area, Punjab, Pakistan
}

\author{
Mirza Naseer Ahmad, Rashida Sultana, Mitsuo Yoshida, and Maria Salahuddin
}

\begin{abstract}
This study was planned to assess the groundwater quality of the District Chiniot, Pakistan. The majority of the people in the area use the groundwater from private wells. Water quality is very poor in the area especially close to the Pre Cambrian exposed Hills. TDS (total dissolved solids), hardness, Chloride, Sulfate and Calcium were very high in groundwater. Trace element chemistry shows that $A s, M n$ and $S$ are above the recommended limit. As and Mn contamination is due to water-rock interaction. Whereas $\mathbf{S}$ is encountered in shallow wells, which may be due to improper solid waste management and septic tanks. Microbiological analysis of municipal supply water shows that $25 \%$ of water samples have faecal contamination. High TDS groundwater is the cause of economic loss due to damage of sanitary fittings.
\end{abstract}

Index Terms-Groundwater contamination, district Chiniot, microbiological contamination.

\section{INTRODUCTION}

Groundwater is the only source of drinking water for many rural areas in developing countries. People are using groundwater without knowing its suitability for drinking and domestic purposes. In most of the cases, water quality is not within the safe limits. The groundwater can be contaminated due to natural processes or human activities. Drinking water quality management is a fundamental requirement in the control and prevention of waterborne diseases. One of the Millennium Development Goals (MDGs) is to increase the number of people who have safe drinking water [1]. Quality analysis of water sources in developing countries can help to achieve this objective through appropriate monitoring. One of the review studies of compiled nationwide data of water contamination reveals that an average of 71 and $58 \%$ samples were contaminated with total coliform and faecal coliform respectively in Pakistan [2]. Several studies have been performed on water quality in Pakistan, and results declared that almost all areas of Pakistan do not have safe drinking water. Major contaminants are microbes, metals especially arsenic and lead as well as saline contamination due to over-extraction of water and reduction in water table [2], [3]. The major concerns are associated with contamination due to

Manuscript received July 9, 2019; revised January 10, 2020. This work was supported by Japan Environment Global Fund and International Network for Environmental and Humanitarian Cooperation, Nonprofit Inc., Tokyo.

M. N. Ahmad, R. Sultana, and M. Salahuddin are with Abdus Salam School of Sciences, Nusrat Jahan College, Rabwah, Pakistan (corresponding author: M. N. Ahmad; e-mail: nmirza@njc.edu.pk, rashida.sultana@njc.edu.pk).

M. Yoshida is with Environmental Research Laboratory of International Network for Environmental and Humanitrian Cooperation (iNehc), Nonprofit Inc., Tokyo, Japan. leaks within the water distribution system and inappropriate built sewer systems. This article is the integration of various studies conducted since 2015 in District Chiniot, Pakistan. The River Chenab flows through the study area and Pre-Cambrian rocks are exposed in the centre of the area. According to the 2017 census, the total population of the District Chiniot is 1.36 million, including 0.947 million in rural areas and 0.422 million in urban areas. The aim of this research is to evaluate and map the physicochemical characterization of the groundwater in district Chiniot. The local population in this district mostly draws water from private wells due to lack of adequate or no water supply supposed to be provided by the local administration [4]. It is very important to know the quality analysis of drinking water either groundwater or supplied by the local administration for suggesting an appropriate solution to eradicate contamination. This study can provide useful information to local residents, administration officers, and planners regarding contamination challenges of drinking water.

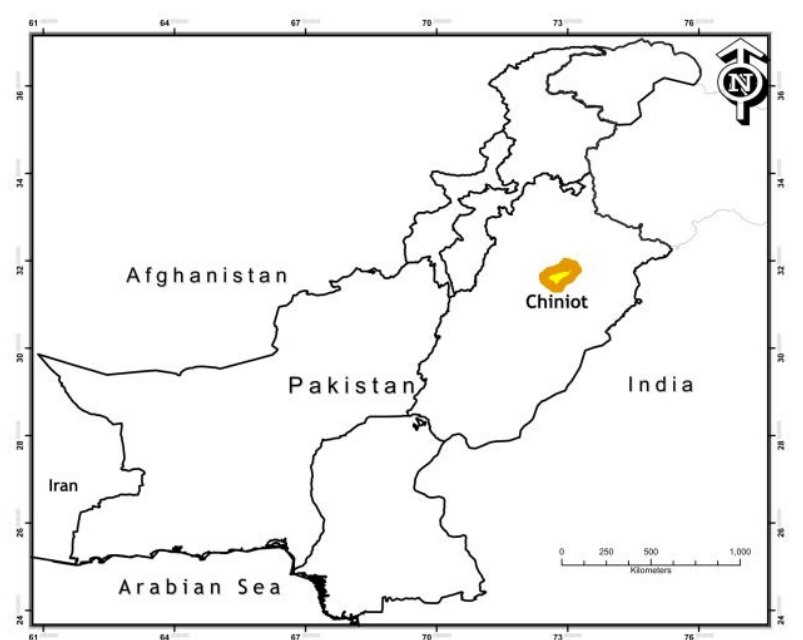

Fig. 1. Location map for the study area. The study area is marked with a yellow polygon.

\section{MethodolOGY}

A survey was conducted to perform Situation Analysis of Safe Drinking Water and Hygiene Conditions in schools of the District Chiniot. In total, 153 schools were selected for the study. Headteacher of each school and one student from each school were interviewed. Structured questionnaires were used to collect data related to safe drinking water. The main issues covered include;

- Main sources, availability, quantity and quality of drinking water in the area.

- Knowledge about water-borne diseases among teachers and students. 
- Behavioural issues related to the treatment of water and the use of safe drinking water.

352 samples were collected from private wells of schools and agriculture tube wells in Chiniot area for analysis of physicochemical parameters. The depth of these wells varied from 35 to 300 feet. The samples were collected along the main roads of the area (Fig. 2). Sampling sites closely spaced near Kirana Hills (Fig. 2 red rectangle; Fig. 3) to study the water quality variation due to the proximity of the shallow basement rocks. Some samples closed to exposed rocks also analyzed for trace elements by using ICP-MS (Inductive Coupled Plasma Mass Spectroscopy). Key analyzed parameters were mapped using GIS technique.

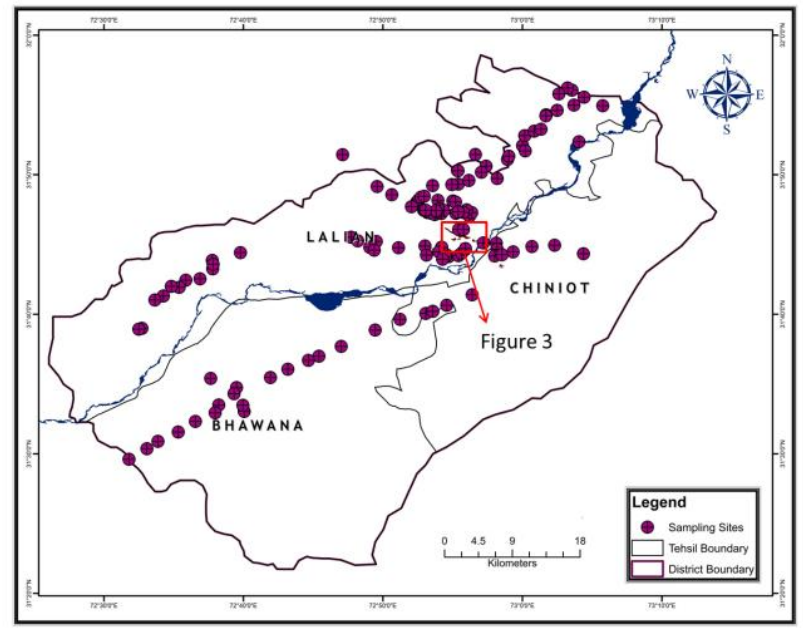

Fig. 2. Location of the sampling sites.

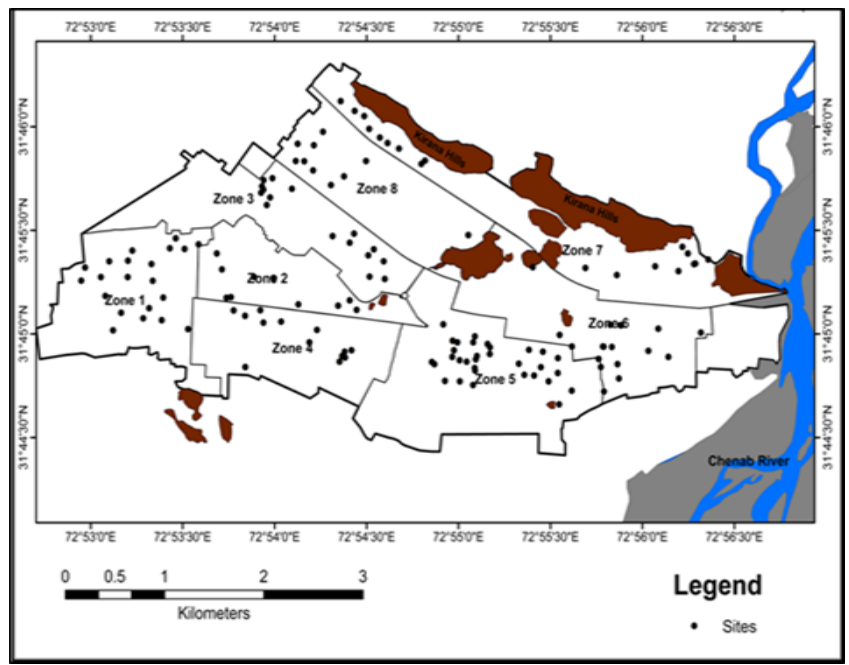

Fig. 3. Sampling location in the vicinity of Kirana Hills.

\section{RESULTS AND DISCUSSIONS}

\section{A. Survey Results}

Key results of the forms are summarized as;

1) Most of the schools have hand pumps (73\%) to withdraw groundwater for drinking purposes. Municipal water supply is only available for $24 \%$ surveyed schools.

2) $14 \%$ head teachers and $20 \%$ of students reported that water was not available in sufficient quantity in their schools.

3) $8 \%$ of students and $6 \%$ of headteachers mentioned that available water has a foul smell.

4) Majority of the headteachers (90\%) and students (75\%) said that drinking water has a specific taste.

5) No government sector school is using any filtering and cleaning technique for drinking water among the surveyed schools.

6) $100 \%$ of students and headteachers were aware of waterborne diseases.

7) Only $26 \%$ of headteachers mentioned that people use any filtering technique in the area.

\section{B. Physiochemical Analysis}

$\mathrm{pH}$ values of the collected water samples are shown in Fig. 4 and Table I. It varies from 6.7 to 8.3. In the case of samples close to Kirana Hills, the pH values are low (Fig. 5). The minimum values of $\mathrm{pH}$ are 5.8. The sub-tehsil Rabwah, that is close to Kirana Hills has only 52\% samples within permissible limits of the WHO guideline [5] (Table II).

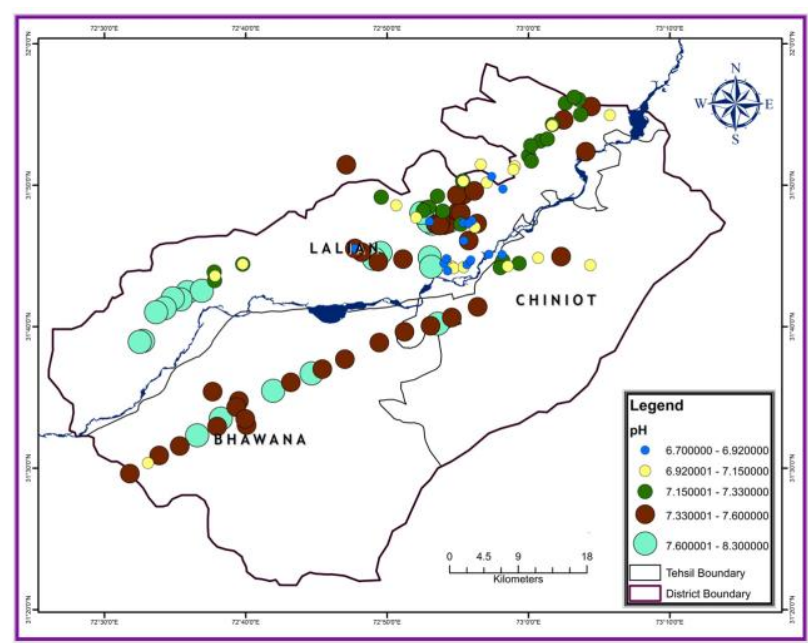

Fig. 4. $\mathrm{pH}$ values of water samples.

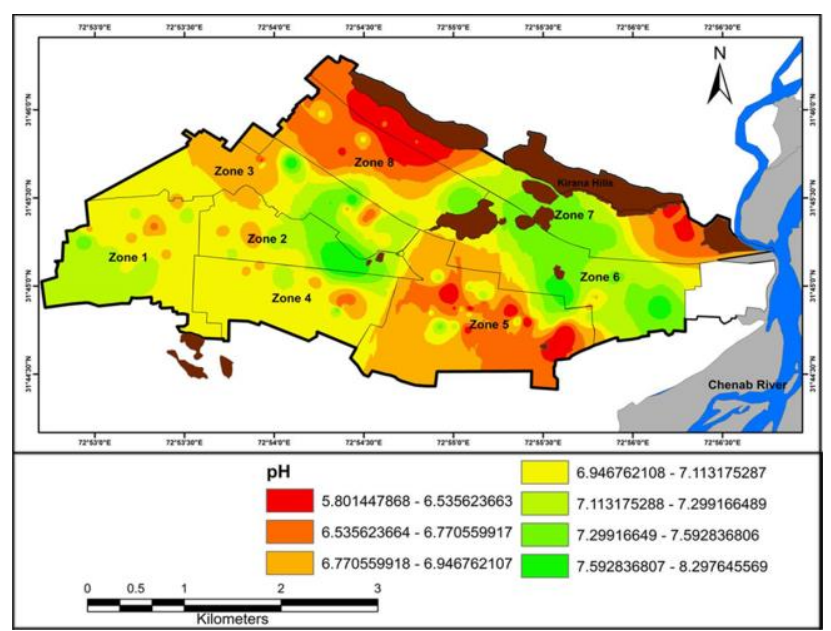

Fig. 5. pH values of samples close to the Kirana Hills. The map is taken from [6].

Low $\mathrm{pH}$ may cause irritation to eyes and skin, and this also has a corrosive effect on fixures [6]

TDS is high in the area. The average value is $780 \mathrm{mg} / \mathrm{L}$ (Table II), which is higher than the WHO guideline. The TDS is very high close to the Kirana Hills. The average value is $2505 \mathrm{mg} / \mathrm{L}$ and the maximum TDS value of groundwater is $12,160 \mathrm{mg} / \mathrm{L}$. Only $16 \%$ of samples are within permissible limits of WHO guideline for District Chiniot (Fig. 6, Table I). 
The fit percentage of analyzed samples in the vicinity of Kirana Hills is only 9\% (Table II).

TABLE I: RESUlTS OF ANALYZED WATER QUALITY PARAMETERS COVERING THE DISTRICT CHINIOT

\begin{tabular}{|c|c|c|c|c|c|c|c|}
\hline Parameters & No. of samples & Min & $\operatorname{Max}$ & Average & Standard Deviation & WHO guidelines & *Fit \% Samples \\
\hline pH & 128 & 6.7 & 8.3 & 7.3 & 0.34 & 7 to 8.5 & 86 \\
\hline EC (uS/cm) & 128 & 220 & 3,070 & 1,075 & 543 & 600 & 20 \\
\hline $\mathrm{HCO}_{3} \mathrm{mg} / \mathrm{L}$ & 128 & 50 & 750 & 318 & 144 & 500 & 94 \\
\hline TDS mg/L & 128 & 161 & 2,000 & 780 & 354 & 500 & 16 \\
\hline Hardness mg/L & 128 & 70 & 1,070 & 391 & 162 & 500 & 82 \\
\hline Calcium mg/L & 128 & 24 & 552 & 167 & 86 & 200 & 72 \\
\hline Magnesium mg/L & 128 & 0 & 519 & 64 & 87 & 150 & 87 \\
\hline Chloride mg/L & 128 & 15 & 1,995 & 194 & 252 & 250 & 72 \\
\hline Sulfate mg/L & 128 & 202 & 1,345 & 139 & 172 & 250 & 87 \\
\hline Sodium mg/L & 68 & 17 & 1,407 & 167 & 235 & 200 & 70 \\
\hline Potassium mg/L & 68 & 15 & 81 & 28 & 9 & ------ & \\
\hline
\end{tabular}

* Parameters according to WHO guideline

TABLE II: RESUlts OF ANALYZED WATER QUALITY PARAMETERS IN ClOSE Vicinity OF KIRANA HILLS WITHIN SUB-TEHSIL RABWAH

\begin{tabular}{|c|c|c|c|c|c|c|c|}
\hline Parameters & $\begin{array}{r}\text { No. of } \\
\text { samples }\end{array}$ & Min & $\operatorname{Max}$ & Average & $\begin{array}{c}\text { Standard } \\
\text { Deviation }\end{array}$ & WHO guidelines & $\begin{array}{r}\text { Fit \% } \\
\text { Samples }\end{array}$ \\
\hline pH & 142 & 5.8 & 8.3 & 6.97 & 0.45 & 7 to 8.5 & 52 \\
\hline EC (uS/cm) & 142 & 420 & 19,920 & 4,584 & 3,572 & 600 & 3 \\
\hline $\mathrm{HCO}_{3} \mathrm{mg} / \mathrm{L}$ & 142 & 50 & 550 & 195 & 95 & 500 & 99.2 \\
\hline TDS mg/L & 142 & 240 & 12,160 & 2,505 & 2,059 & 500 & 9 \\
\hline Hardness mg/L & 40 & 140 & 3,700 & 827 & 636 & 500 & 32 \\
\hline Calcium mg/L & 40 & 48 & 680 & 209 & 139 & 200 & 25 \\
\hline Magnesium mg/L & 40 & 5 & 500 & 82 & 95 & 150 & 90 \\
\hline Chloride mg/L & 40 & 90 & 8,048 & 1,241 & 1,482 & 250 & 20 \\
\hline Sulfate mg/L & 40 & 202 & 2,131 & 884 & 258 & 250 & 2.5 \\
\hline Nitrate mg/L & 40 & 1.66 & 8.89 & 4.24 & 2.75 & 50 & 100 \\
\hline Fluoride mg/L & 40 & 0.029 & 0.074 & 0.047 & 0.009 & 1.5 & 100 \\
\hline
\end{tabular}

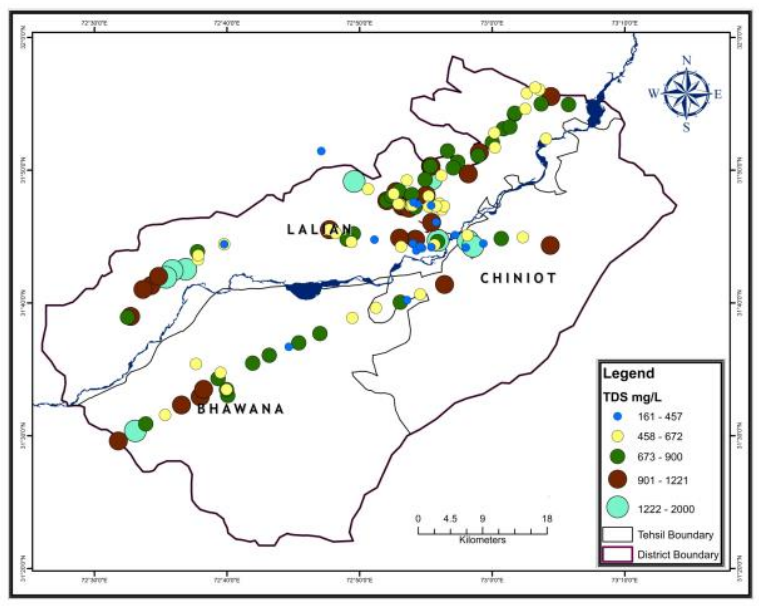

Fig. 6. TDS values of water samples within District Chiniot.

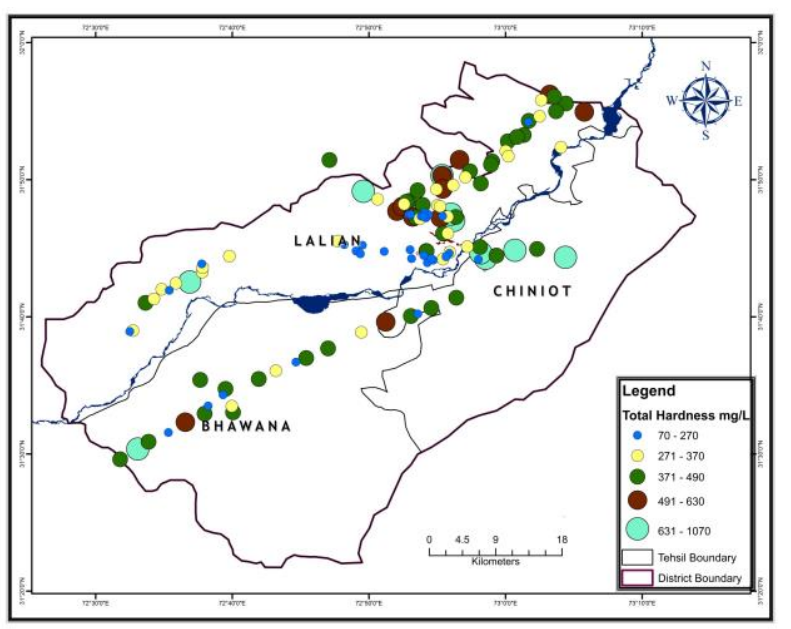

Fig. 7. Total hardness map within the District Chniot.
Hardness is one of the important parameters of water quality for drinking and domestic uses. Majority of the samples $(82 \%)$ are fit for the guideline value of hardness and the average hardness $(391 \mathrm{mg} / \mathrm{L})$ is below the permissible limits of the WHO guideline (Fig. 7, Table I). However, the detailed sampling close to the Kirana Hills indicates that the average hardness $(636 \mathrm{mg} / \mathrm{L})$ is greater than the WHO guideline (Table II). Fig. 8 indicates that extremely high hardness is observed close to the Kirana Hills.

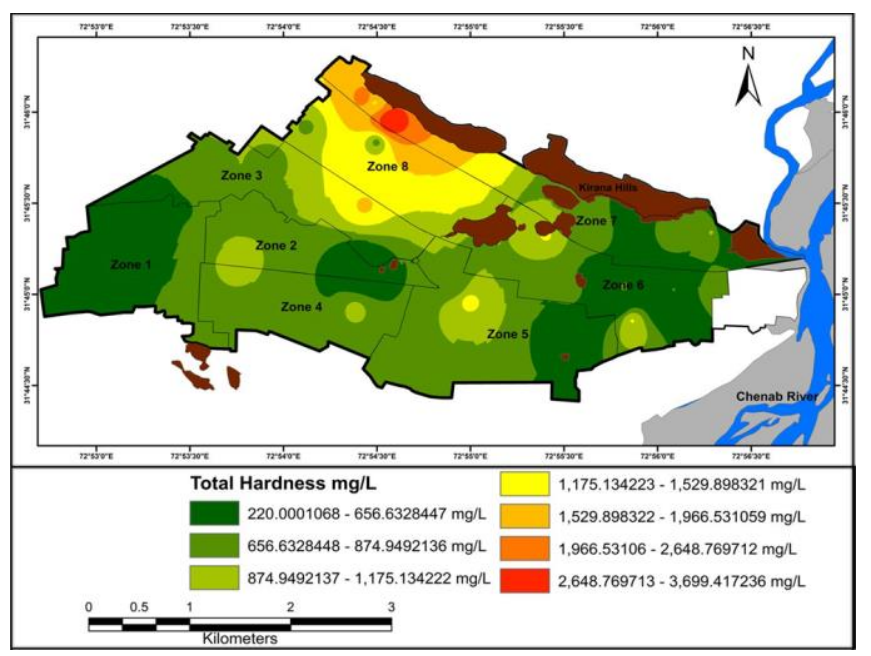

Fig. 8. Interpolated hardness map close to the Kirana Hills in the sub tehsil Rabwah. This map is taken from [5].

The average value of $\mathrm{Ca}$ within the district Chiniot is 169 $\mathrm{mg} / \mathrm{L}$, that is less than the limit of WHO guideline $(200 \mathrm{~g} / \mathrm{L})$. $72 \%$ of the samples are fit regarding WHO guidelines. Whereas, only $25 \%$ of the samples were within the 
permissible limits of WHO guideline in the vicinity of Kirana Hills (Table II).

However, the majority of the samples throughout the district show $\mathrm{Mg}$ concentration within the limits of WHO guideline (Table I \& Table II).

The high concentration of $\mathrm{Cl}$ was observed in water samples of the area close to the Kirana Hills. The average value of Chloride $(1,241 \mathrm{mg} / \mathrm{L})$ is far above the maximum permissible concentration of $250 \mathrm{mg} / \mathrm{L}$ (Table II). High levels of Chloride cause corrosion and shorten the life span of pipes, pumps, hot water heaters and other fixtures [7].

The sulfate values in groundwater samples are within the prescribed upper limit of the WHO guideline (Table I). However, close to the Kirana Hills, the sulfate values are very high. The average value of sulfate concentration was 884 $\mathrm{mg} / \mathrm{L}$, which was significantly higher than the recommended upper limit of WHO guideline. The presence of sulfate in drinking water results in noticeable taste and it may have laxative effects on the digestive system of human beings.

According to ICP-MS analysis, Yoshida and Ahmad (2018) [8] reported the concentration of As and Mn in groundwater exceeded the drinking water quality standards of WHO guideline (Table III). As rich and Mn-rich minerals, arsenopyrite $(\mathrm{FeAsS})$ and cryptomelane $\left(\mathrm{K}\left(\mathrm{Mn}^{4+}\right.\right.$, $\left.\mathrm{Mn}^{2+}\right)_{8} \mathrm{O}_{16}$ ), were found in the basement rocks of Kirana Hills, which suggests that groundwater contamination is probably derived from these rocks and their debris in the groundwater basin through a water-rock interaction. Arsenic is a naturally occurring element, but long-term exposure can cause cancer in people. Manganese is an essential element for many living organisms, including humans. For example, some enzymes require manganese, and some are activated by the element. Adverse health effects can be caused by inadequate intake or overexposure of Mn [9]. The ICP-MS analysis also detected a high concentration of $\mathrm{Cl}, \mathrm{Br}$, and $\mathrm{S}$.

TABLE III: TRACE ELEMENT CONCENTRATION ( $\mu \mathrm{G} / \mathrm{L})$ IN GROUNDWATER IN CHINIOT AREA (DATA SOURCE: YoshidA AND AHMAD (2018) [8]).

\begin{tabular}{|l|l|l|l|l|}
\hline $\begin{array}{l}\text { Trace } \\
\text { element }\end{array}$ & Samples & Max & Min & $\begin{array}{l}\text { WHO } \\
\text { guideline } \\
\text { value }\end{array}$ \\
\hline $\mathrm{As}$ & 14 & 25.1 & 2.3 & 10 \\
\hline $\mathrm{Mn}$ & 14 & 443 & 4.35 & 50 \\
\hline
\end{tabular}

\section{Water Quality Deterioration with Time}

Water quality (TDS) record was examined for two turbines supplying water to part of Rabwah town of District Chiniot. Since 2005 TDS of both turbines increased.This increase of TDS is related to over-exploitation of water from the aquifer.

\section{Microbiological Contamination}

Polymerase chain reaction (PCR) was used to detect coliform in 100 water samples of municipal water supply. Main supply distributary is not contaminated. $25 \%$ of the water samples have faecal contamination. Out of $25 \%, 95 \%$ have pathogenic E coli strains. This contamination may be due to the improper sewerage system. Generally, water storage tanks are underground and distance between drains and water storage tank is found less than $1 \mathrm{ft}$. Open drains appear to be the reason for seepage into underground water storage tanks.

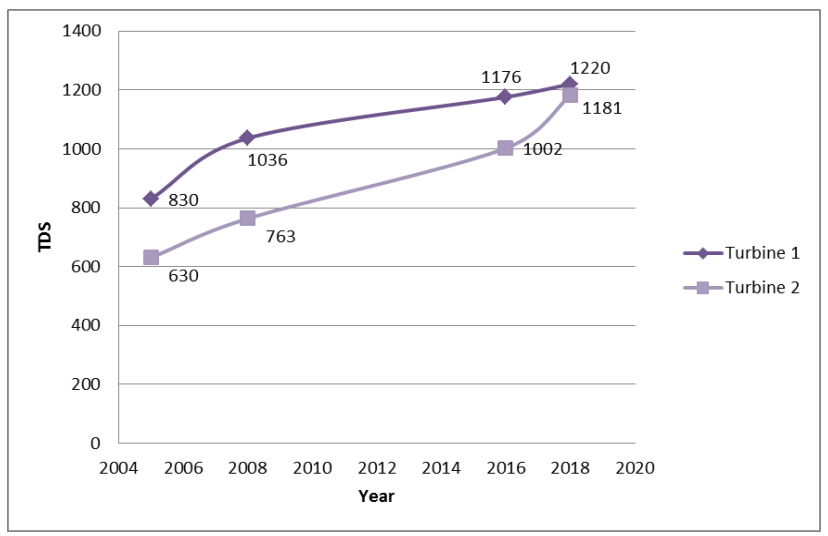

Fig. 9. Long-term variation of TDS (mg/L) of ground-water collected from Turbines 1 and 2, Rabwah, Chiniot.

\section{E. Economic Loss Due to Poor Quality of Water}

High TDS water can cause damage to sanitary items such as taps, marble floors, showers, geysers and boilers [10]. A survey was conducted among residents living close to Kirana Hills, where water quality of groundwater is very poor to determine the economic loss of sanitary items. According to the survey results from people using high TDS water spending approximately 14,000 rupees annually for the repair of the sanitary items [11]. Poor water quality is also causing economic loss to local residents.

\section{CONCLUSIONS}

The following findings and conclusions can be summarized as;

1) The study findings highlighted a number of problems regarding the availability of water, poor wash and sanitation facilities in many schools of the District Chniot.

2) The average values of Total Dissolved Solids, Hardness, Calcium, Chloride and Sulfate were extremely high in the areas close to the Kirana Hills.

3) Some trace elements such as As and Mn were observed in groundwater samples of the area, which may cause health problems.

4) Pathogenic Ecoli contamination has been found in the municipal supply water. Therefore, an awareness program is required to inform the local population regarding appropriate filtering techniques in order to avoid public health issues.

\section{CONFLICT OF INTEREST}

The authors declare no conflict of interest

\section{AUTHOR CONTRIBUTIONS}

Mirza Naseer Ahmad conducted fieldwork and wrote the paper. Rashida Sultana and Maria Salahuddin conducted laboratory analysis and analyzed data. Mitsuo Yoshida conducted the analysis for trace element composition of water and rocks.

\section{ACKNOWLEDGMENT}

Miho W. Yoshida of iNehc is thanked for providing guidance regarding the social impact of the project. 


\section{REFERENCES}

[1] WHO. (2001). Water health and human rights. The world water day. [Online]. Available: https://www.who.int/water_sanitation_health/en/humanrights.htm

[2] F. Nabeela et al., "Microbial contamination of drinking water in Pakistan - A review," Environmental Science and Pollution Research vol. 21, no. 24, pp. 13929-13942, 2014.

[3] M. K. Daud et al., "Drinking water quality status and contamination in Pakistan," BioMed Research International, 2017.

[4] B. A. Tahir et al., "Access to safe drinking water and wash facilities in schools of District Chiniot, Pakistan and awareness on waterborne diseases among teachers and students," International Journal of Economic and Environmental Geology, vol. 9, no. 4, pp. 20-25, 2018.

[5] WHO. (2003). $\mathrm{pH}$ in drinking water WHO/SDE/WHO/03.04/12. [Online]. Available: http://www.who.int/water_sanitation_health/dwq

[6] M. N. Ahmad et al., "Assessment of groundwater resources in Kirana hills region, Rabwah, district Chiniot, Pakistan," International Journal of Economic and Environmental Geology, pp. 54-58, 2016.

[7] S. B. Adeloju and H. C. Hughes, "The corrosion of copper pipes in high chloride-low carbonate mains water," Corrosion Science, vol. 26, no. 10, pp. 851-870, 1986.

[8] M. Yoshida and M. N. Ahmad, "Trace element contamination of groundwater around Kirana Hills, District Chiniot, Punjab, Pakistan," International Journal of Economic and Environmental Geology, vol. 9, no. 4, pp. 12-19, 2018.

[9] World Health Organization, "Manganese in drinking-water: Background document for development of WHO Guidelines for Drinking-water Quality (No. WHO/SDE/WSH/03.04/104)," World Health Organization, 2004.

[10] H. Browett, M. Pearce, and E. M. Willis, "Cost implications of hard water on health hardware in remote Indigenous communities in the central desert region of Australia," The International Indigenous Policy Journal, vol. 3, no. 3, p. 6, 2012.

[11] R. Sultana et al., "Economic impact assessment of brackish groundwater in Kirana Hills region, District Chiniot, Pakistan," International Journal of Economic and Environmental Geology, pp. 19-24, 2019.
Copyright $(92020$ by the authors. This is an open access article distributed under the Creative Commons Attribution License which permits unrestricted use, distribution, and reproduction in any medium, provided the original

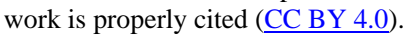

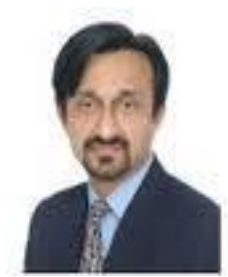

Mirza Naseer Ahmad received a Ph.D from Hokkaido University, Sapporo, Japan. He is currently working as head of the Department Earth Sciences Department, Abdus Salam School of Sciences, Nusrat Jahan College, Rabwah, Pakistan. His main interests are environment, hydrology and exploration geophysics.

Rashida Sultana received the MPhil degree in botany from University of Lahore. She is currently working as a lecturer at Abdus Salam School of Sciences, Nusrat Jahan Colege, Rabwah, Pakistan. She has been involved in environmental monitoring projects, water quality analysis and soil remediation.

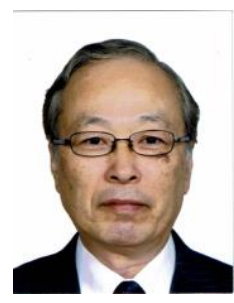

Mitsuo Yoshida graduated and received Ph.D from Hokkaido University, Sapporo. His main interest is environmental management and protection in the developing world. $\mathrm{He}$ is $\mathrm{CEO} /$ director of Environmental Research Laboratory, International Network for Environmental and Humanitarian Cooperation, Nonprofit Inc., Tokyo, and also advisor of Global Environment Department, Japan International Cooperation Agency (JICA), Tokyo.

Maria Salahuddin has earned her master's degree in geography from Government College University Faisalabad (GCUF). She has been working on various projects of remote sensing and GIS. 